\title{
SUBCHRONIC TOXICITY TEST OF COMBINATION ETHANOL EXTRACT OF DETAM 1 SOYBEAN (GLYCINE MAX L. MERR) AND JATI BELANDA (GUAZUMA ULMIFOLIA LAMK) TOWARD FUNCTION, WEIGHT, AND HISTOPATHOLOGICAL OF WISTAR RAT LIVER
}

\section{MEILINAH HIDAYAT ${ }^{1}$, SIJANI PRAHASTUTI ${ }^{2}$, ESTHEROLITA DEWI ${ }^{3}$, DEWI SAFITRI ${ }^{4}$, SITI FARAH RAHMAWATI ${ }^{4}$, ANDREANUS A SOEMARDJI ${ }^{4}$}

${ }^{1}$ Department of Nutrition, Maranatha Christian University, Bandung, Jawa Barat, Indonesia. ${ }^{2}$ Department of Biochemistry, Maranatha Christian University, Bandung, Jawa Barat, Indonesia. ${ }^{3}$ Faculty of Medicine, Maranatha Christian University, Bandung, Jawa Barat, Indonesia. ${ }^{4}$ Pharmacology Clinical Pharmacy Research Group, School of Pharmacy Bandung Institute of Technology, Jalan Prof Drg. Suria Sumantri, MPH No 65, Bandung - 40163, Jawa Barat, Indonesia. Email: mellahidayat@yahoo.com

Received: 03 June 2016, Revised and Accepted: 20 June 2016

\section{ABSTRACT}

Objective: As an antiobesity therapy, combination extracts of Detam 1 soybean and Jati Belanda will be consumed for a long time; therefore, their toxicities to the liver need to be investigated. To determine the effect of subchronic toxicity test of combination of ethanol extract of Detam 1 soybean (EEDS) and ethanol extract of Jati Belanda (EEJB) on liver function with parameters: Alanine transaminase (ALT), macroscopic, and histopathological of liver

Methods: This study was conducted on 120 Wistar rats (60 males and 60 females), 90 days (treatment group) and 120 days (satellite group). Rats were divided into six treatment groups ( 3 test materials, 1 control, and 2 satellites); each group included 10 males and 10 females.

Results: ALT levels of treatment groups (low dose, medium, and high), both males and females were lower than the control group (p<0.05). The treatment groups demonstrated a good effects effect on liver function. Liver weight of all groups showed no significant difference compared with the control group ( $p>0.05$ ). Results of histopathological score interpretation of male and female liver rats of low dose groups were not disturbed; middle dose groups were slightly disturbed and high dose groups were damaged. Satellite high doses of male groups were disrupted, while female groups were not.

Conclusion: The combination of EEDS and EEJB has a good effect on liver function, did not lead to change organ weight and at low doses did not cause renal histopathology damage in rats after 90 days administration.

Keywords: Combination of soybean Jati Belanda, Toxicity subchronic test, Function, Weight, Histopathology, Liver.

(C) 2016 The Authors. Published by Innovare Academic Sciences Pvt Ltd. This is an open access article under the CC BY license (http://creativecommons. org/licenses/by/4. 0/) DOI: http://dx.doi.org/10.22159/ajpcr.2016.v9i5.13237

\section{INTRODUCTION}

Obesity is major risk factors for a number of chronic diseases including diabetes, cardiovascular diseases, and cancer and is now dramatically on the rise. One alternative to overcome is efficacious use of medicinal plants. Most people assume that all medicines derived from plants are safe and without side effects. Drugs consumed for a long time should be examined and tested for their safety and side effects.

According to pharmacokinetic aspect, all drugs will be metabolized until they are completely eliminated from the body. Through oral administration, the absorption is commonly happen throughout the intestine which will be followed by metabolism in the liver. The active substances of the drug will be carried into the bloodstream and liver, so the liver is always exposed to potentially toxic materials. The longer contact time and the higher concentration of the active substances contained in drugs, the potential for liver damage will be higher [1].

Transaminase enzyme/aminotransferase is an indicator or index that is sensitive for detecting disease hepatoseluler [2]. When liver cells damaged, the enzyme transaminase will be spread out from the liver, so the levels in the blood will increase. Serum glutamic-pyruvic transaminase or alanine transaminase (ALT) can be detected more specific for liver damage because the level is dominant on the liver cell [3].

Previous studies have found that histopathological changes in the liver of rats treated with a single ethanol extract of Jati Belanda (EEJB) single ethanol extract of Detam 1 soybean (EEDS) and the combinations indicate that administration of a single extract EEJB tend to be hepatotoxic, whereas single effect EEDS cause liver histopathologic improvement. The combined extract with the proportion of EEJB:EEDS (2:1) lead to worsened the liver histopathologic features on the contrary effect on weight showed better results $[4,5]$

Detam 1 soybean (Glycine max L. Merr) comes from the plantation of Tubers and Nuts Research Department in Malang. The preliminary study examined the effect of soybean on body weight male Wistar rats for 14 days with the different treatments of 11 types of extracts, indicated that extract which has the most activity on bodyweight loss is extract of Detam 1 soybean protein at dose of $20 \mathrm{mg} / \mathrm{kg} \mathrm{BW}(\mathrm{p}=0.022)[6,7]$. Iswantini stated that the methanolic extract of Jati Belanda leaves var Bogor has inhibition activity on pancreatic lipase, while extract of Jati Belanda leaves from Bumi Herbal Dago plantations is expected to be a therapeutic target of antiobesity [8].

The combination of EEDS and EEJB has been proven in reducing bodyweight loss and antihiperlipidemia [9-11]. It supposed to be consumed for relatively long time. Hence, a subchronic toxicity testing is needed.

In this study, we conducted subchronic toxicity tests on the effect of EEDS and EEJB combination in vivo for 90 days on the hepatic function, with parameters ALT, gross macroscopic and histopathological of Wistar male and female liver. 
The aim of this study was to determine the subchronic toxicity after 90 days administration of EEDS and EEJB combination to macro and micropathology of Wistar rats liver function, followed by observation for the next 30 days (satellite) for groups without any treatment and with high dose treatment.

\section{METHODS}

The material used is EEDS and EEJB, which produced by a simple maceration process using ethanol $96 \%$. A total of 120 Wistar rats 60 males and 60 females, 6-8 weeks old weighing between 150 and $200 \mathrm{~g}$ - were randomly divided into six groups ( 3 test materials, 1 control, and 2 satellites) each of 10 male rats and 10 female rats, then adapted for 7 days. All groups were treated for 90 days and were observed for 90 days, except in the satellite group was observed for 120 days in accordance with the toxicity tests guidance from National Agency for Drug and Food Control (Balai Pemeriksaan Obat dan Makanan/ BPOM) $[12,13]$. In the treatment groups, rats were administrated with combination of EEKD and EEJB at a ratio of 1:2 in multiple doses for 90 days. Negative control group was only provided with solvent distilled water and $0.5 \%$ carboxymethyl cellulose (CMC). Group 1: A low dose, Group 2: Intermediate dose, and Group 3: High dose; EEKD: EEJB $=50: 100 \mathrm{mg} / \mathrm{kg} /$ day, EEKD: EEJB=100: $200 \mathrm{mg} / \mathrm{kg} /$ day, and EEKD: $E E J B=200: 400 \mathrm{mg} / \mathrm{kg} /$ day, respectively. Satellite group negative control, only administrated with distilled water solvent, and CMC 0.5\%, and satellite group high dose (EEKD:EEJB $=200: 400 \mathrm{mg} / \mathrm{kg} /$ day) for 120 days.

The parameters measured were as follows: (1) ALT level after 90 days, using the colorimetric method with Roche Cobas 131 apparatus on days 91 and 121, (2) weight of liver organ of all groups using a an analytical balance with a precision of three digits after the decimal point, and (3) examination and analysis of histopathological preparations hematoxylin-eosin staining of Wistar rat liver organ. The parameters used to assess is the modification and adaptation of several study [14-16], i.e., architectural feature of the liver in general, the size of hepatocytes, necrosis of hepatocytes, dilation of sinusoid, venous congestion centralis (percentage of swelling), bleeding around the vein centralis, inflammation, and fibrosis of the liver cells. To make simple comparison among groups of damage, all interpretation converted into scores and summed.

Differences between groups were analyzed by one-way ANOVA, Mann-Whitney U, Kruskal-Wallis, and Chi-square tests as appropriate. Data were checked for normality by visual inspection of the normal probability curves and with the Shapiro-Wilk test of normality, followed by Tukey honestly significant difference test, with a limit of significance $\alpha<0.05$. The histopathological analysis of liver preparations was analyzed semi-quantitatively in score system and was totally summed.

\section{RESULTS}

After 90 days administration of the negative control group, low dose G1, G2, and G3 medium dose of high dose, then on day 91 serum ALT levels were assessed. The satellite groups were examined in the next 30 days and on day 121, the ALT levels of satellite control group and high dose satellite were measured. The results are shown in Fig. 1. The level of ALT serum and statistical analysis are provided in Tables 1-3.

Based there are significant differences between low, middle, and high dose group on male and female in control group, the ALT levels were significantly lower, mean that administration of the test material did not cause an increase in alanine aminotransferase levels. For high dose group, there is a significant different as compared to the control group both in low and middle dose. Satellite control high dose group showed a significant difference as compared to satellite control group $(\mathrm{p}<0.05)$. After 30 days washout period, good ALT levels in high dose are performed.

On day 91, the rats were sacrificed, and the weight of liver organ in the negative control group, low dose G1, G2 middle dose, and G3 high dose

Table 1: ALT serum levels on male and female Wistar rats in different groups of treatment

\begin{tabular}{|c|c|c|c|c|c|}
\hline \multirow[t]{2}{*}{ Group } & \multirow[t]{2}{*}{$\mathbf{n}$} & \multicolumn{2}{|l|}{ Male } & \multicolumn{2}{|l|}{ Female } \\
\hline & & Average & SD & Average & SD \\
\hline Group control negative & 10 & 67.60 & 12.607 & 167.20 & 13.612 \\
\hline G1 dose low & 10 & 56.00 & 10.965 & 132.80 & 9.705 \\
\hline G2 dose middle & 10 & 52.40 & 7.074 & 110.70 & 6.183 \\
\hline G3 dose high & 10 & $35.40^{*}$ & 3.169 & $84.70^{*}$ & 6.701 \\
\hline Satellite control & 10 & 55.00 & 10.541 & 127.10 & 9.550 \\
\hline Satellite dose high & 10 & $32.90 *$ & 3.035 & $74.80^{*}$ & 4.077 \\
\hline $\begin{array}{l}\text { Result of homogeneity } \\
\text { test variance }\end{array}$ & 0.032 & & & 0.131 & \\
\hline $\begin{array}{l}\text { ANOVA } \\
\text { Tukey HSD* }\end{array}$ & $0.000^{*}$ & & & $0.000^{*}$ & \\
\hline
\end{tabular}

${ }^{*}$ The mean difference is significant at the 0.05 level. SD: Standard deviation, ALT: Alanine transaminase

Table 2: Different advanced test averages Tukey HSD of male Wistar rats

\begin{tabular}{lllllll}
\hline Group & Group control & Group 1 low & Group 2 middle & Group 3 high & Satellite control & Satellite D high \\
\hline Group control & & $*$ & $*$ & $* *$ & $*$ & $*$ \\
Group 1 low & & NS & $* *$ & NS & $* *$ \\
Group 2 middle & & & & NS & $* *$ \\
Group 3 high & & & & $* *$ & NS \\
Satellite control & & & & $* *$ \\
Satellite D high & & & & \\
\hline
\end{tabular}

*: Significant, **: Highly significant, NS: Non-significant

Table 3: Different advanced test averages Tukey HSD of female Wistar rats

\begin{tabular}{|c|c|c|c|c|c|c|}
\hline Group & Group control & Group 1 low & Group 2 middle & Group 3 high & Satellite control & Satellite D high \\
\hline Group control & & $* *$ & $* *$ & $* *$ & $* *$ & ** \\
\hline Group 1 low & & & NS & $* *$ & NS & $* *$ \\
\hline Group 2 middle & & & & $* *$ & NS & $* *$ \\
\hline Group 3 high & & & & & $* *$ & NS \\
\hline Satellite control & & & & & & $* *$ \\
\hline Satellite D high & & & & & & \\
\hline
\end{tabular}

**: Highly significant, NS: Non-significant 
was weighed. Satellite groups were sacrificed at the next 30 days, on day 121 . Table 4 shows the weight of rats' liver.

Liver organ of male and female Wistar rats in treatment groups were not significant $\mathrm{p}=0.099$, and $\mathrm{p}=0.270$, respectively, as compared to the control group.

\section{Histopathological analysis of liver organ male Wistar rats}

The liver was weighed, soaked in a solution of $1 \%$ formalin, with stained with hematoxylin-eosin for histopathology preparations. Then, analyzed under a light microscope with 100 and $\times 400$ magnification and conducted semi-quantitative interpretation by scoring. The parameters used are architectural feature in general, the size of hepatocyte cells, necrosis of hepatocytes, sinusoidal dilation, congestion of central vein, bleeding around vicinity of the central vein, inflammation, and fibrosis. Comparison of damage of each group, the result of interpretation was converted into scores and summed up. Results of resumes obtained from each group are listed in Tables 5 and 6.

The results of histopathological score is summarized in the Table 7 . Results total scores of male control group were 12.3; females 18.25; G1 low dose males 17.4, females 19.5; G2 medium dose males 27.6, females 27.7; G3 high dose males 49, females 52.6; satellite control males 17.2;

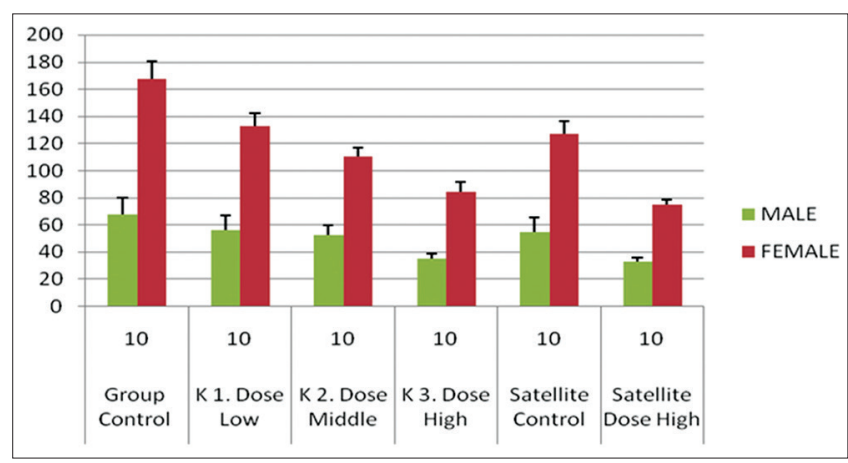

Fig. 1: Alanine transaminase serum levels on male and female Wistar rats in different groups of treatment

Table 4: Weight of on male dan female Wistar rats' liver

\begin{tabular}{lllllll}
\hline \multirow{2}{*}{ Group } & $\mathbf{n}$ & \multicolumn{2}{l}{ Male } & & \multicolumn{2}{l}{ Female } \\
\cline { 3 - 4 } & & Average/gr & SD & & Average/gr & SD \\
\hline Group control & 10 & 6.61 & 0.56 & & 5.71 & 1.20 \\
K1 dose low & 10 & 6.12 & 0.73 & 6.44 & 0.89 \\
K2 dose middle & 10 & 6.29 & 1.56 & 6.73 & 1.42 \\
K3 dose high & 10 & 6.30 & 1.30 & 6.10 & 0.82 \\
Satellite control & 10 & 6.91 & 1.11 & 6.93 & 0.84 \\
Satellite dose high & 10 & 7.61 & 1.23 & 6.24 & 0.85 \\
Sig ANOVA & & 0.099 & $(\mathrm{p}>0.05)$ & 0.270 & $(\mathrm{p}>0.05)$ \\
\hline
\end{tabular}

SD: Standard deviation females 26.8 and 31.2 the satellite high dose males and the female the result is very low: 9.2. The results of microscopic observation on liver male and female rats at low dose group showed no damaged, for middle dose group of male and female slightly distracted and satellite high dose male group was severely damaged, while the female was very good, and not disturbed. Liver organ of female rats had an excellent recovery in 30 days.

\section{DISCUSSION}

The ALT levels, in general, however were lower in male than female rats. The ALT levels of treatment groups (low dose G1, G2 medium, and high G3), both males and females showed significantly lower than the negative control group, indicated that the treatment did not cause an increase in ALT. It was concluded that the provision of material test did not interfere the ALT, but on the contrary, it showed a good effect on liver function. There was no chemical parameter-related pathological change, so the changes were not considered to be toxicologically significant.

Genistein, an isoflavone in soybean is powerful antioxidants, significantly lowered tumor necrosis factor alpha plasma and prevented emerge of non-alcoholic fatty liver disease through stress reduction oxidative mechanism [17]. High level of antioxidants in EEDS will reduce oxidative stress so that the liver cell damage can be prevented, as shown by stable or lower ALT level [18].

The lowest level of ALT was observed in G3 high dose group and high dose control satellite, means that the higher the dose, the better the ALT levels. The combination of appropriate natural materials provides synergistic effects, sum up the antioxidant activities and protective the liver from damage $[19,20]$. Isoflavones, flavonoids, and tannins contained in EEDS and EEJB are known to have antioxidant properties suppress the free radicals [18-20] However, the active substance in EEJB causes liver damage is not clearly defined, exacerbating histopathologic Fig. 2 of liver cells, as shown in the previous study $[4,5]$. Moreover, optimal dose of antioxidants is not yet known, many studies on this field were needed, but in that study, if the dose increased, the results got better. In this study, administration of the test substances showed a positive effect on liver function, adverse effects of Jati Belanda might be suppressed by antioxidants in Detam 1 soybean [18-20].

The liver weights of all groups showed no significant difference as compared to the control group ( $p>0.05)$; it is concluded that the test material did not damage the liver cells as shown by no change in macroscopic of liver organ.

The interpretation of preparations histopathology score of G1 low dose group both male and female showed that their livers were not disturbed. G2 medium dose and high dose G3 slight disturbed and damaged in satellite high doses male group. Giving high doses of the test substance has the potential to have a cumulative effect and postponed effect against the male rat liver, seen by disturbed histopathologic feature of satellite high dose group, after 30 days later. The dose tested

Table 5: Histopathological of liver preparation Hepar male Wistar rats

\begin{tabular}{llllll}
\hline Liver score & $\begin{array}{l}\text { Group } \\
\text { control }\end{array}$ & $\begin{array}{l}\text { Group 1 } \\
\text { low }\end{array}$ & $\begin{array}{l}\text { Group 2 } \\
\text { middle }\end{array}$ & $\begin{array}{l}\text { Group 3 } \\
\text { high }\end{array}$ & $\begin{array}{l}\text { Satellite D } \\
\text { high }\end{array}$ \\
\hline Architectural feature & 1 & 3 & 7 & 11 & 7 \\
control
\end{tabular}




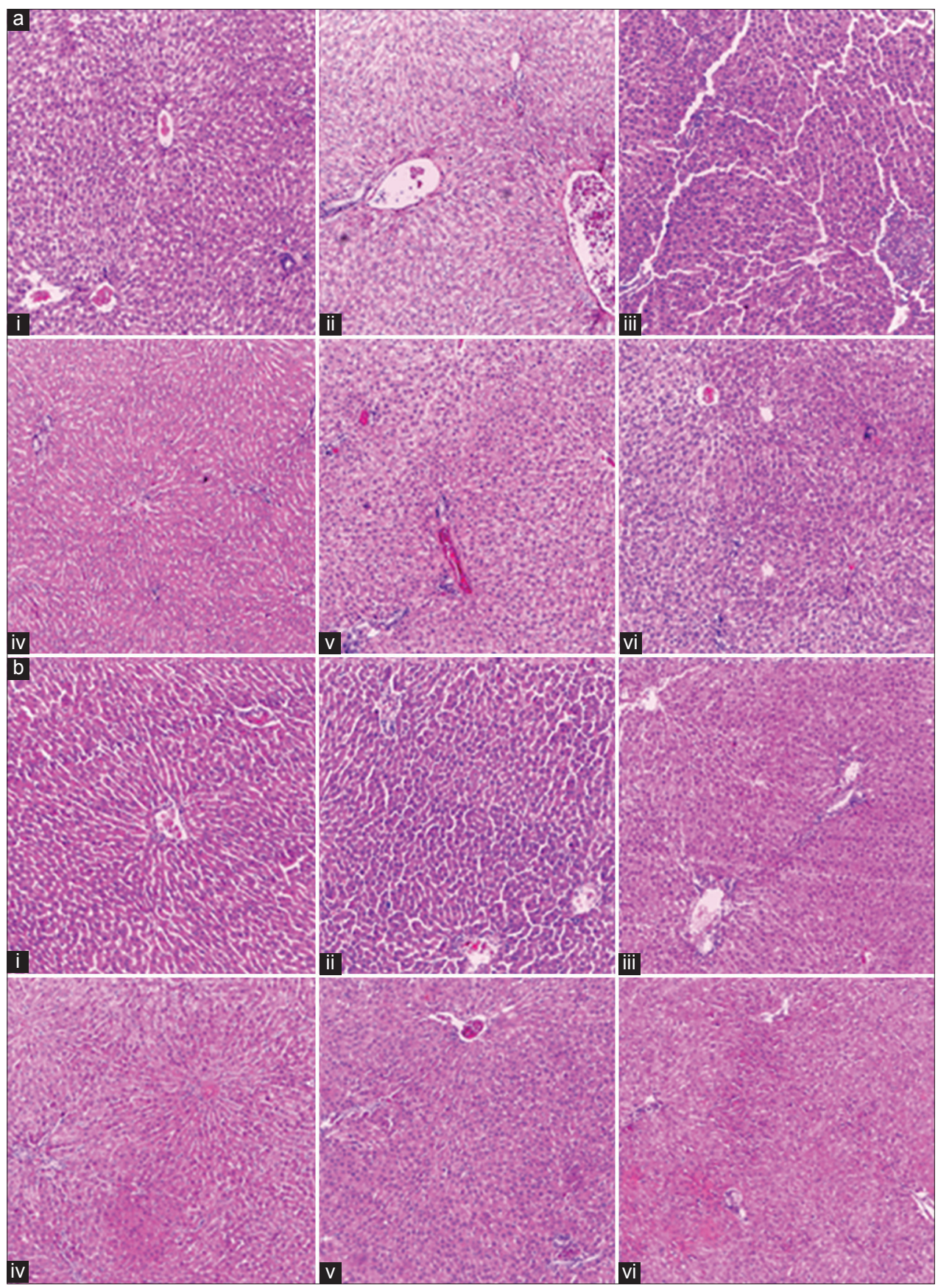

Fig. 2: (a) Female. (i) Female low dose, (ii) female middle dose, (iii) female high dose, (iv) female negative control, (v) female satellite control, (vi) female satellite high dose. (b) Male. (i) Male low dose, (ii) male middle dose, (iii) male high dose, (iv) male negative control, (v) male satellite control, (vi) male satellite high dose

is equivalent to dose which is $600 \mathrm{mg} \times 56=33600 \mathrm{mg}$ or $33.6 \mathrm{~g}$ for human. The use of low dose (the used dose for therapeutic), i.e., $150 \times$ $56=8400 \mathrm{mg}$ is still within a safe limit for health.

In female rats, administration of high dose satellite group was good restoration of liver cells after 30 days, as compared to the control group. It might be due to the induction of the test substances on female hormones which facilitate liver cell repair. If we compare to another study, no observed adverse effect level (NOAEL) of black soybean (G. max) hull extract was found to be $5074.1 \mathrm{mg} / \mathrm{kg}$ body weight/day for males and $7617.9 \mathrm{mg} / \mathrm{kg}$ body weight/day for females in mice [21] The toxic dose for female is higher than in male mice; it is concluded that the effects on hepatic histopathological differ in males and females.

\section{CONCLUSION}

A combination of EEDS and EEJB extracts shows a significant effect on the liver function, and maintains the organ weights, and it is safe and no interference to the liver histopathology at low doses and NOAEL at dose of $8400 \mathrm{mg} / \mathrm{kg}$ body weight/day for humans.

\section{ACKNOWLEDGMENT}

The authors thank the Directorate General of Higher Education of the Republic of Indonesia for Research Grant No. SP-DIPA 023.04.1.673453/2015 dated 14 November 2015 Revision 01, dated March 3, 2015. Our thanks to Dr. Roro Wahyudianingsih Sp. PA who 
Table 6: Histopathology preparation Hepar rats female

\begin{tabular}{|c|c|c|c|c|c|c|}
\hline Liver score & $\begin{array}{l}\text { Group } \\
\text { control }\end{array}$ & $\begin{array}{l}\text { Group } 1 \\
\text { low }\end{array}$ & $\begin{array}{l}\text { Group } 2 \\
\text { middle }\end{array}$ & $\begin{array}{l}\text { Group } 3 \\
\text { high }\end{array}$ & $\begin{array}{l}\text { Satellite } \\
\text { control }\end{array}$ & $\begin{array}{l}\text { Satellite D } \\
\text { high }\end{array}$ \\
\hline Architectural feature & 0 & 2 & 2 & 12 & 0 & 0 \\
\hline Size of hepatocyte cells & 1 & 1 & 4 & 8 & 1 & 0 \\
\hline Necrosis of hepatocytes & 0 & 0 & 0 & 3 & 0 & 0 \\
\hline Sinusoidal dilation & 5 & 4 & 8 & 10 & 5 & 0 \\
\hline Congestion of centralis $\mathrm{v}$ & 4.25 & 3.5 & 2.7 & 3,6 & 2.8 & 1.2 \\
\hline Bleeding around centralis $\mathrm{v}$ & 1 & 0 & 0 & 0 & 0 & 0 \\
\hline Fibrosis & 0 & 2 & 3 & 4 & 6 & 2 \\
\hline Total scores & 18.25 & 19.5 & 27.7 & 52.6 & 26.8 & 9.2 \\
\hline
\end{tabular}

0: Not damaged, 1: Very slightly damaged, 2: Slightly damaged at $1 / 4$ of the visual field, 3: Damaged $1 / 4$ the visual field, 4: $1 / 2$ slightly damaged on the field of vision, 5: $1 / 2$ damaged the visual field, 6 : Badly damaged in $1 / 2$ of the visual field, $7: 3 / 4$ heavily on visual field, $8: 3 / 4$ heavily on visual field, 9 damaged at $>3 / 4$ of the visual field, 10: Severely damaged the entire field of view

Table 7: Total scores of histopathological analysis of liver male and female Wistar rats

\begin{tabular}{lll}
\hline Group & Total scores \\
\cline { 2 - 3 } & Male & Female \\
\hline Control & 12.3 & 18.25 \\
Dose low & 17.4 & 19.5 \\
Dose middle & 27.6 & 27.7 \\
Dose high & 49 & 52.6 \\
Satellite control & 17.2 & 26.8 \\
Satellite high & 31.2 & 9.2 \\
\hline
\end{tabular}

Score 10-20: Not damaged at all; considered the same as control, 21-30: Slightly damaged, 31: Damaged

has helped making preparations for histopathology, analysis, and interpretation of histopathology PA, and Ingrid S Surono, MSc, Ph.D., for English editing assistance.

\section{REFERENCES}

1. Fatmawati A. Pengaruh Pemberian Ekstrak Daun Jati Belanda Dosis Bertingkat Terhadap Hepar Tikus Wistar. Semarang. Repository: Fakultas Kedokteran Universitas Diponegoro; 2008.

2. Behrman ER, Kliegman RM, Arvin MA. Ilmu Kesehatan Anak Paediatrics. Nelson. Vol. 2. Jakarta: EGC; 2000.

3. Yayasan Spiritia. Penjelasan Tes Fungsi Hepar Warta AIDS. San Diego: Yayasan Spiritia; 2001. p. 1

4. Vera E. Gambaran Histopatologis Hepar Terhadap Pemberian Ekstrak Etanol Biji Kedelai Detam 1 dan Daun Jati Belanda Serta Kombinasinya pada Tikus Wistar Jantan Yang Diinduksi Pakan Tinggi Lemak. Bandung. Repository: Universitas Kristen Maranatha; 2015.

5. Hidayat M, Soeng S, Wahyudianingsih R, Ladi JE, Krisetya YA, Elviora V. Ekstrak Kedelai Detam 1, daun Jati Belanda serta Kombinasinya terhadap Berat Badan dan Histopatologis Hepar Tikus Wistar. JKKI 2015;6(4):167-78.

6. Hidayat M, Kurnia D, Sujatno M, Sutadipura N, Setiawan I. Perbandingan kandungan makronutrisi dan isoflavon dari biji, tempe dan ekstrak kedelai detam 1 dan wilis serta potensinya dalam menurunkan bobot badan. Bionatura J Ilmu Hayati dan Fisik 2010;12(1):5-13.

7. Hidayat M, Sujatno M, Sutadipura N, Setiawan I. Effect several soybean (Glycine max L. Merr) extracts to food intake, body weight and cholecystokinin plasma in rats. Majalah Ilmu Faal Indonesia 2009;8(3), 151-8.

8. Iswantini D, Silitonga RF, Martatilofa E, Darusman LK. Zingiber cassumunar, Guazuma ulmifolia, and Murraya paniculata extracts as antiobesity: In vitro inhibitory effect on pancreatic lipase activity.
Hayati. J Biosci 2011;18:1

9. Hidayat M, Soeng S, Prahastuti S. Characteristics of combination of ethanol extract detam 1 soybean (Glycine max L. Merr) and ethanol extract of jati belanda leaves (Guazuma ulmifolia) in potential inhibition of pancreas lipase enzyme. International Seminar on Natural Product of Medicine. Poster, Bandung Institute of Technology; 2012.

10. Krisetya YA, Hidayat M, Soeng S. Perbandingan Efek Ekstrak Etanol Kedelai Detam 1, Jati Belanda dan Kombinasinya terhadap Penghambatan Kenaikan Berat Badan tikus Wistar Jantan yang diinduksi Pakan Tinggi Lemak. Bandung. Repository. Universitas Kristen Maranatha; 2013.

11. Hidayat M, Soeng S, Prahastuti S, Tiono H, Krisetya YA, Sugiono M. Characteristics of ethanol extract of detam 1 indonesian soybean, jati belanda leaves and the effets of their combinations to weight gain and the jejunum histopathological changes in male wistar rats. Eur J Med Plants 2015:7(2):87-98.

12. BPOM. Badan Pengawas Obat dan Makanan Republik Indonesia Peraturan Kepala Badan Pengawas Obat dan Makanan Republik Indonesia Nomor 7 Tahun 2014 tentang Pedoman Uji Toksisitas Nonklinik Secara In vivo.

13. OECD, Organization for Economic Cooperation and Development. Guidelines for Testing of Chemicals. Paris: OECD;2001. p. 407-8.

14. Singh K and Arora SP. Effect of feeding salseed-meal tannins on histopathology of some organs and amino acid uptake. Indian J Anim Sci $1982 ; 52(2): 84-8$

15. Omar HM, Hassan KA, Elghafar ASKh, and Ahmend EA. Aluminium toxicity in rats: The role of tannic acid as antioxidant. Ass Univ Bull Environ Res 2003;6(2)1-14.

16. Karimi H, Kia HD, Hosseinkhani A. Histological effects of different levels of sorghum grain on the liver and Kidney of ghezelxarkhar merino crossbred lambs. Anim Vet Sci 2014;2(4):130-4.

17. Hartini. Studi Tentang Efek Antioksidan Vitamin E dengan Parameter SGOT dan SGPT Serum Darah Tikus Putih (Rattus novergicus) yang Dipapar Asap Rokok. Biology; 2006. p. 1.

18. Hidayat M, Soeng S, Prahastuti S, Hermanto PT, Andhika YK Aktivitas Antioksidan dan Antitrigliserida Ekstrak Tunggal Kedelai, Daun Jati Belanda serta Kombinasinya. Bionatura J Ilmu Hayati dan Fisik. 2014;16(2): 89-94.

19. Hermanto PT. Aktivitas Antioksidan Ekstrak Etanol Biji Kedelai (Glycine max (L.) Merr) Varietas Detam 1, Daun Jati Belanda (Guazuma ulmifolia) dan Kombinasinya. Bandung. Repository: Fakultas Kedokteran Universitas Kedokteran Maranatha; 2013.

20. Koshy AS, Anila L, Vijayalakshmi NR. Flavonoids from Garcinia cambogia lower lipid levels in hypercholesterolemic rats. Food Chem 2001;72:289-94.

21. Fukuda I, Tsutsui M, Yoshida T, Toda T, Tsuda T, Ashida H. Oral toxicological studies of black soybean (Glycine $\max$ ) hull extract: Acute studies in rats and mice, and chronic studies in mice. Food Chem Toxicol 2011;49(12):3272-8. 